\title{
The Literacy of Tropical Community and the Needs for Tropical Environment-Based Learning
}

\author{
$1^{\text {st }}$ Lambang Subagiyo \\ Mulawarman University, Indonesia \\ subagiyo.pplhunmul@gmail.com \\ $2^{\text {nd }}$ Zeni Haryanto \\ Mulawarman University, Indonesia \\ zeni.haryanto@fkip.unmul.ac.id
}

\author{
$3^{\text {rd }}$ Sudarman \\ Mulawarman University, Indonesia \\ $4^{\text {th }}$ Herliani \\ Mulawarman University, Indonesia
}

\begin{abstract}
East Kalimantan is one of the areas in the tropical rainforest environment that has abundant natural resources. It needs a new paradigm about the utilization of natural resources. The future intellectual candidates must realize that the utilization of natural resources must be harmony with the environment. The purposes of this study were to know the literacy of the students of Mulawarman University about the tropical rainforest environment, the literacy about the utilization and management of tropical rainforest environment, and the literacy about culture and local wisdom. Data obtained using questionnaires, interviews and FGD. The respondents were students and lecturers. The results showed that $63.75 \%$ of students did not have good literacy about the tropical rainforest, but more than $87.5 \%$ of respondents had a good paradigm about tropical forest conservation and $70 \%$ of respondents did not have good literacy about the concept of natural resource utilization based on tropical rainforest. Mulawarman University has successfully managed to build culture and local wisdom developed through the diffusion of technology to students. In order to produce competitive and adaptable graduates, Mulawarman University will refine curriculum that meets the competencies required in living in accordance with the uniqueness of East Kalimantan.
\end{abstract}

Keywords: Mulawarman University, tropical forest, natural resources, competence

\section{INTRODUCTION}

East Kalimantan province is located between $113^{\circ} 444^{\prime} \mathrm{E}$ $119^{\circ} 00^{\prime} \mathrm{E}$, and between $2 \mathrm{o} 33^{\prime} \mathrm{N}-2 \mathrm{o} 25^{\prime} \mathrm{S}$. It has vast land and sea with the total area of $127,267.52 \mathrm{~km} 2$ and $25,656 \mathrm{~km} 2$, respectively. Most areas of the province are heterogenous forest with high humidity and rainfall, hence the forest area in East Kalimantan is often called as tropical rainforest. Tropical rainforest is a wide-leaved forest that is always green with very high density of trees. [1]
The tropical rainforest of East Kalimantan has abundant natural resources. The natural resources are used to fulfill the needs of native life. In line with the culture and local wisdom, natural resources utilized by the conservation principles to maintain sustainability. However, technological developments and cultural shifts feared to have an impact on the utilization of natural resources and the preservation of tropical forests, while the local community is not ready for the development of modern culture.

Utilizing inappropriate natural resources can make the environment unstable so that it has a bad impact on society. Republic of Indonesia Law No. 32 of 2009 concerning environmental protection and management must be the basis for increasing the commitment of users and stakeholders to conserve natural resources, because the community has the right to live in a clean and healthy environment.[2] This is very relevant to the meaning contained in Article 28H of the 1945 Constitution that everyone has the right to live in physical and spiritual well-being, to own a home and enjoy a good and healthy environment. Therefore, a new paradigm needs to be built for young intellectuals in managing natural resources.[3]

To protect and manage the environment, it must implement based on the principles of: (a) state responsibility; (B) preservation and sustainability; (c) harmony and balance; (d) alignment; (e) benefits; (f) caution; (g) justice; (h) ecoregions; (i) biodiversity; (j) participation; (k) local wisdom; (l) good governance; and (m) regional autonomy. As a result of people's understanding and perspective as well as the motivation and interests of those who exploit natural resources often ignore aspects of environmental protection and good management. As a result, environmental damage occurs continuously, sometimes even the quality of the environment is far from feasible.[4]

The various effects of the utilization of natural resources such as mining exploitation, deforestation, and 
burning of peatlands are now being perceived, like increased carbon emissions, critical land, floods, increased sedimentation rates and micro-climate change. The direct and indirect impacts can decrease the productivity and fertility of agricultural land, and that will lead to further impacts on food security, economic decline, social conflicts, decreased levels of public health.

In order to control the rate of utilization of natural resources and prevent damage to tropical forests in Borneo, it has required a change of perspective about the natural resources of Kalimantan. People should think far into the future to conserve natural resources, endemic plants and local wisdom that has long developed on Kalimantan. Therefore, the intellectuals of East Kalimantan should be able to think to maintain and preserve nature and natural resources.

A significant effort is to build a new paradigm of future intellectual candidates to realize that the utilization of natural resources should be harmony with the environment. Young intellectuals should understand about biodiversity their area and know how to manage natural resources in a sustainable way. The refinement of the curriculum at the Mulawarman University is expected to change the paradigm of intellectuals in East Kalimantan and equip students to plan a life in a tropical rainforest environment and conduct sustainable development with cultural and local wisdom-based behavior [5]

Revitalization of the Curriculum at Mulawarman University is believed to be able to produce graduates' capabilities that are able to explore scientific concepts that are relevant to natural conditions in Kalimantan such as literacy in tropical forests, for example, mining management, agroforestry, creative economy, tropical diseases, public health in the rainforest region tropical, social and local culture. Learning is designed to improve the ability of learning and life-based learning in accordance with the characteristics and carrying capacity of the environment in Kalimantan. To optimize the process and learning outcomes, it is necessary to develop models, tools and teaching materials in accordance with the characteristics of students at Mulawarman University.

The efforts carried out by the Mulawarman University in implementing the scientific principal pattern, i.e. tropical rainforest studies and the university's great vision, is mapping paradigm and literacy about tropical rainforest, such as to know the literacy of students of Mulawarman University about the tropical rainforest environment, the literacy of students about utilization and management of a tropical rainforest environment, the literacy of students and stakeholders about culture and local wisdom as the effort to developed life-based curriculum in Mulawarman University [6]. It is expected that this program will be able to change the paradigm of Mulawarman University graduates in facing modern life with preserving the environment as well as able to utilize and manage the environment of East Kalimantan tropical forests in a sustainable manner [7].
Based on Law of the Republic of Indonesia No. 41 of 1999 , forest has three functions, i.e. functions of conservation, functions of protection and functions of production. Furthermore, the government determines the forest based on its main function, which are conservation forest, protected forest, and production forest. The forest as a protected function intended for the protection of soil and water for the surrounding area. As a conservation function of forest area with particular characteristics that are intended for the protection of nature, preservation of flora and fauna, nature tourism and science purposes. While the forest as a production function plays to produce timber and other forest products to support the economy of the country and community [8].

The threats of tropical rainforest deforestation usually originate from a variety of power levels, local, national, and international level. The threats of deforestation in East Kalimantan usually result from (1) commercial logging, both legally or illegally; (2) mining, whether by small miners with traditional technology as well as by big miners with advanced technology; (3) land clearing by local residents for making permanent agricultural land; (4) the opening of palm oil plantations and industrial plantation forest; (5) shifting cultivation; (6) exploitation of non-timber forest products; and (7) the various major infrastructure development projects.

The concept of natural resources conservation must be prioritized, particularly in the utilization of renewable natural resources, the natural resource capital stocks should be still maintained and always at the optimum point. Meanwhile, the strategies of non-renewable natural resources utilization should be used with high-efficiency level and still seek the substitution. The government should organize with their instruments in the utilization of natural resources, with a macro vision is to create a sustainable ecology, and micro vision is to maintain sustainable diversity.

\section{METHOD}

According to Joyce, Weil, and Calhoun, "A model of The strategy to explore the data in this study is by (1) spreading the questioner to the respondents to obtain data (2) conducting interviews, Focus Group Discussion with students and stakeholders and observation of faculty documents at Mulawarman University, (3) mapping a New Paradigm of Higher Education Oriented on Capability Development and (4) analyzing learning needs and competencies of students in order to improve the curriculum at Mulawarman University. Total respondents in this study are 200 people.

The data analysis in this study is conducted by categorizing the answers given by the respondents as described in Table 1 . 
TABLE I CATEGORIZATION OF STUDENTS' LITERACY ON TROPICAL RAINFORESTS

\begin{tabular}{|c|c|c|}
\hline Conceptual Literacy (\%) & $\begin{array}{c}\text { Cultural Literacy } \\
(\boldsymbol{\%})\end{array}$ & Category \\
\hline$\leq 30$ & $\leq 30$ & Very low \\
$31-50$ & $31-50$ & Low \\
$51-70$ & $51-70$ & Medium \\
$71-85$ & $71-85$ & High \\
$>86$ & $>86$ & Very high \\
\hline
\end{tabular}

\section{RESULTS AND DISCUSSION}

In general, the conceptual literacy of students on tropical rainforests was still limited to defining the definition of forest and has not been able to explain the literacy on technology utilization and innovation properly. Based on the results of data analysis of student questionnaires, basically, the students did not have good concept literacy about tropical rainforests in East Kalimantan. The most of the students have a good consideration to the conservation of the tropical forest environment. However, the students' understanding has not been matched by real action in environmental conservation. With a good understanding about tropical rainforest in East Kalimantan, students are expected to have a good paradigm about tropical forest management.

Although their understanding of the environmental carrying capacity of tropical forests has not been maximal, their understanding about tropical rainforest preservation is very good. The students gave very good answer about their commitment to conserving the tropical rainforests, which reached $88 \%$. Students also realized the need of optimizing the tropical rainforests resources in East Kalimantan and the effort of increasing production ability based on tropical rainforest, which is $86 \%$ of total students. About $92 \%$ of students also agree that the community should be able to be self-sufficient with its natural resources. In order to be self-sufficient, about $91 \%$ of students considered that it necessary to utilize the diversity of their natural resources. The students' perception of technological innovation is also very high, which is at $96 \%$, which means that students of Mulawarman University did not refuse to the use of modern technology, or in other words that the literacy on technology has been high

Based on the result of the study of the students' literacy on the utilization of forest resources and their environment, dengan indikator (a) the perception aspect about the utilization of tropical forest, (b) the utilization of natural resources and (c) the understanding of sustainability of natural resources, is still quite low. About $63.75 \%$ of respondents have not been able to give a good answer and their perception about the utilization of tropical forests has not been consistent, as shown in Fig 1.

The concept of conservation of natural resources must be prioritized, especially in the use of renewable natural resources, capital reserves of natural resources must be maintained and always at an optimal point. Indicators on Literacy of natural

resource conservation are (a) utilization of natural resources based on mining (b) literacy on mining and utilization of natural resources (c) investment of natural resources in a broad sense is also still quite low, which has not reached $70 \%$ as shown in Fig 2 .

Percentage Respon Of Respondents

80

60

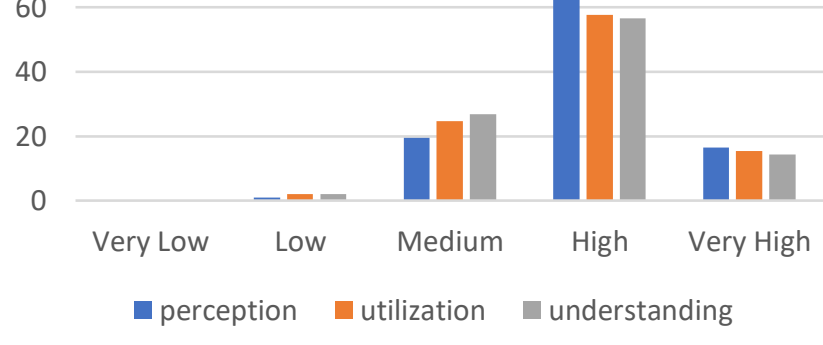

Fig 1 The literacy of students about forest resources and the environment utilization.

The role of Mulawarman University in improving the society and intellectual paradigm of East Kalimantan in the future is to provide broader facilities through the development of a curriculum based on tropical studies so that all faculties can provide courses on tropical rainforests, its utilization, and management. The University must also always encourage the government to carry out the development that prioritizes the aspects of environmental conservation, that is building a green economy. Student and community wisdom must be built in addressing the problems of natural resources and the environment. Current development should not rely solely on natural resources. Thus, the strengthening of stakeholders who are able to conserve the environment and natural resources need to be developed. Including exploring local values (local wisdom) to support the sustainable environmental management.

\section{Pencentage of Literacy}

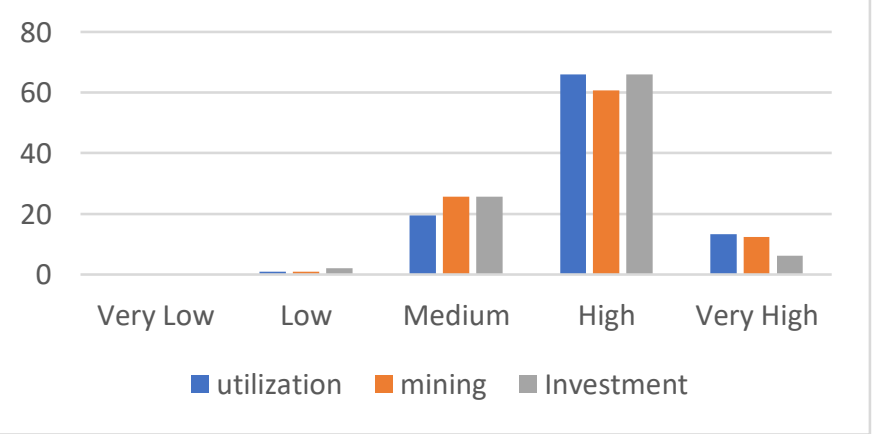

Fig 2 The literacy of students about mining and natural resources utilization and investment. 
The specific competencies to be developed in each faculty should not only be oriented on the utilization of natural resources primary products, but must be oriented to derivative products and innovations in natural resource management based on modern industry, for example the department of mining engineering provides competencies of exploration, exploitation and mining management in modern tropical rainforest environment and eco-friendly. The faculty of pharmacy should develop pharmaceutical development research based on tropical plants for tropical diseases. The faculty of economics develops green economy programs, agriculture and sustainable agroforestry, etc. If all faculties provide special competencies in accordance with the scientific principal pattern of Mulawarman University, which is the study of tropical rainforest, it is believed that Mulawarman University can produce multidisciplinary experts in the tropical rainforest. The ultimate goal expected is to build a prosperous and innovative life tropical rainforest community.

Based on the results, culture and local wisdom literacy judged has not been optimal. Shown in Fig 3, score of three indicators, which are technology literacy, innovating consciousness and confidence about the management and conservation of tropical forest is still less than $60 \%$. Mulawarman University as a research university always develops study about the culture and local wisdom in an effort to maintain culture and local wisdom of Kalimantan. Some aspects of culture that are supposed to be built are (a) literacy about keeping the "carrying capacity" in a tropical forest environment (b) intensification of utilization of resources with minimal environmental damage (d) literacy about renewable resources conservation and resources utilization efficiency (d) innovation for replacing the use of non-renewable resources (e) literacy about the use of eco-friendly technology.

The literacy of culture and local wisdom should also be developed in every faculty that oriented to the management and conservation of tropical forest. The curriculum of Mulawarman University must also be adjusted to the special competencies that must be mastered by the students, thus providing competence on the ability to live in accordance with the uniqueness of the region and its natural wealth.

Based on the study results of students' literacy about local resources management and conservation awareness, the university has provided academic services as needed in improving student productivity in managing local resources. The competence of lecturers of Mulawarman University in (a) facilitating students to innovate in various production processes, (b) the literacy about natural resources and (c) adaptation literacy is already quite good, as shown in Fig 3. More than $80 \%$ of respondents said that the competence of natural resource management is good. Based on the results of interviews conducted for students, it can also be described that the basic competence in the utilization and management of natural resources is good. Data support from FGD results with stakeholders of Mulawarman University showed that the commitment of lecturers to improve student's competence is very high.

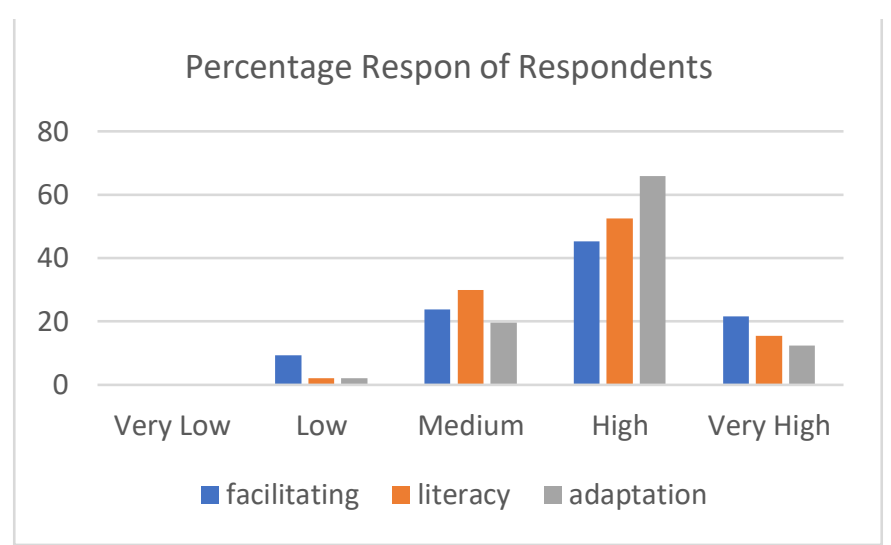

Fig 3. The literacy of students about innovation and utilization of technology

Students of Mulawarman University also have a good awareness towards the conservation of tropical forests. By the support of curriculum developed by the university, it is believed that to be able to provide space and time for students to understand the literacy of living in East Kalimantan. In addition, the course study materials presented in the curriculum of Mulawarman University have provided space and knowledge to students to preserve and conserve the tropical rainforest environment with indicators (a) in creating and innovating (b) adaptability (c) productivity to manage local resources and (d) the ability to titrate managing local resources, as shown in Fig 4. It can be seen that the data distribution is good, but still needs to be improved. Based on the FGD results of the curriculum, it appears that all faculty representatives have attempted to improve the special competence of students in accordance with the principal scientific pattern of Mulawarman University, with indicators (a) understand life literacy in East Kalimantan (b) concern for the preservation of tropical forests and (c) adaptive to life in a tropical rainforest environment, as shown in Fig 5.

Mulawarman University as a university with a scientific principal pattern of tropical forestry studies should be able to create research on eco-friendly technology engineering through research institutions and studies in college. Things that can be conducted are (a) technology development for mitigation for environmental degradation (b) technology development for environmental assessment of tropical forests (c) conducting studies for development of eco-friendly resources utilization system (d) study materials development on environmental law enforcement and innovative instruments for the prevention of pollution as well as environmental and tropical forest degradation (e) teaching culture and local wisdom.

Based on study results, the literacy of science and technology, culture and local wisdom of Mulawarman 
provide literacy for student adaptation with rainforest-based life.

University students is quite good, but still, need to be further developed. Research data as shown in Fig 6 shows that the literacy of living with culture and local wisdom to adapt to modern life, the literacy on the existence of modern cultural shifts that can change the culture and local wisdom of society, and the ability of Mulawarman University in unifying various cultures and local wisdom in East Kalimantan became a modern life and able to preserve the environment of tropical rainforest are considered very good.

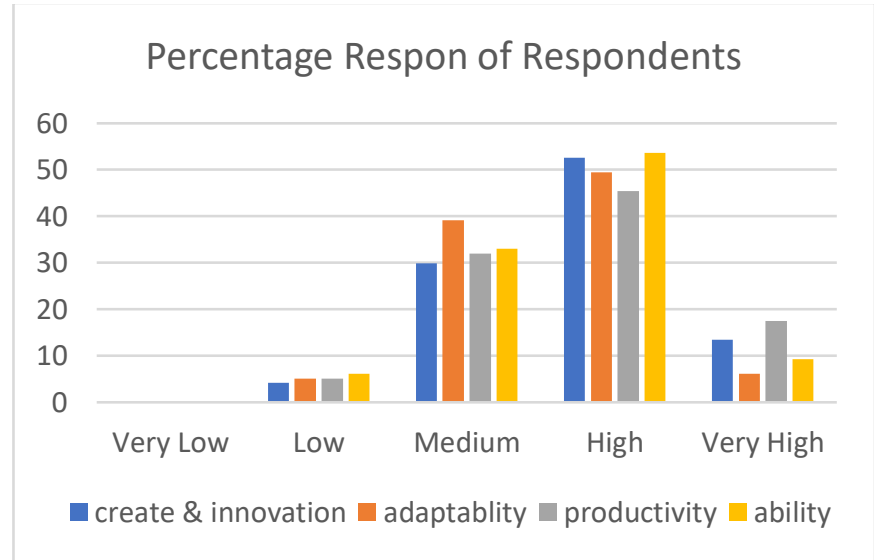

Fig 4. The ability of the Mulawarman University Curriculum providing space and knowledge to students for the conservation of tropical rainforest.

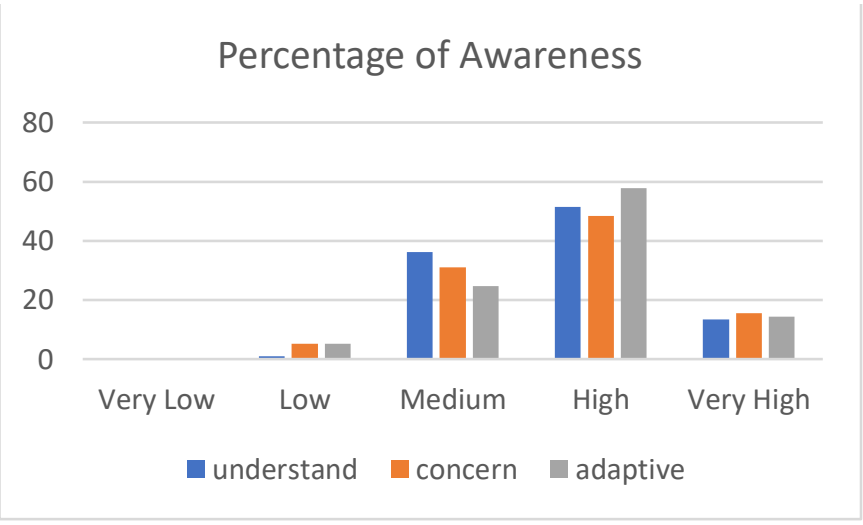

Fig 5. The literacy students about living with culture and local wisdom to adapt and live in a tropical rainforest environment.

Indicators of students' cultural literacy in adapting to modern life include (a) the beliefs of students and alumni of Mulawarman University that they are able to adapt to culture and local wisdom-based life in East Kalimantan and modern life, (b) the commitment of Mulawarman University students to have knowledge and character that is able to adapt in East Kalimantan and tropical rainforest environment and (c) the ability of Mulawarman University to conduct technology diffusion to
From the research, it can be shown that more than $80 \%$ of students have strong beliefs that they are able to adapt to modern life and recognize that Mulawarman University has had diffused technology according to the needs.

The ability of students to live based on culture and local wisdom has succeeded well, it means that Mulawarman University has been able to bring students to life on campus as well as in society. The university has been able to bring the students live harmoniously without any argument even though in Mulawarman University campus there are multi-ethnic (Javanese, Bugis, Banjar, Dayak, Kutai, etc.) and multicultural originated from various regional and cultural archipelago, however harmonious can be created.[9]

In the internalization of culture and local wisdom to the students are given in basic natural science and basic sociocultural science courses. In the basic natural science course, it should be discussed deeply about tropical rainforest, characteristics of management and efforts in conserving natural resources. While in the basic socio-cultural science course, it should be developed study materials about the culture and local wisdom in living in tropical forest environment, characteristics of culture and local wisdom in utilizing natural resources, and multi-ethnic life harmonization.

Mulawarman University has succeeded in developing a harmonious campus in life. It should be fostered to ensure that the ability to live well in tropical rainforest with diverse ethnicities and cultures. It means that the culture and local wisdom in living already successfully implemented by civitas academic of Mulawarman University. But the things that still need to be developed is how the culture and local wisdom in the conservation of natural resources in implementing sustainable development.

\section{CONCLUSION}

Based on this study, it can be concluded that the students of Mulawarman University have not had good literacy about tropical rainforest concept, however, they already have good paradigm and commitment about environmental conservation of tropical forest. Stakeholders have had the same paradigm about the scientific principal pattern of tropical rainforest studies, so they have agreed to refine the curriculum of tropical studies to equip students with the competence to adapt and innovate in life within tropical rainforest environment. The literacy of Mulawarman University students about the utilization and management of tropical rainforest environment is quite low, but the students have well understood the natural resource management technologies in the tropical forest environment. On the aspect of culture and local wisdom, Mulawarman University is able to create a harmonious campus life, students and stakeholders in Mulawarman University have had high enough literacy about local wisdom and culture. Culture and local 
wisdom have been internalized in the life of students and stakeholders for rainforest conservation.

\section{REFERENCES}

[1] BPS Kaltim. 2016. Kalimantan Timur in Figures. Saamarinda: Sekar Mulya.

[2] Undang-undang Republik Indonesia Nomor 32 Tentang Perlindungan dan Pengelolaan Lingkungan Hidup.

[3] August P. Silaen, 2008, Pelestarian Fungsi Hutan Dan Lingkungan Hidup Dalam Perspektif Hukum Lingkungan, VISI (2008) 16 (3) 575 - 594)

[4] Ahmad Sihabudin, Literasi Media Dengan Memberdayakan Kearifan Lokal Jurnal Communication Vol. 4 No.2 (2013)
[5] Permenristek Dikti. 2014. Pedoman Pengembangan Kurikulum LPTK. Jakarta: Direktorat Jenderal Pendidikan Tinggi.

[6] Sibel Karuduman, The role of critical media literacy in further development of consciousness of citizenshi, Procedia - Social and Behavioral Sciences 174 ( 2015 ) 3039 - 3043

[7] Serhat Arslan, The Influence of Environment Education on Critical Thinking and Environmental Attitude, Procedia - Social and Behavioral Sciences 55 (2012) $902-909$

[8] Undang-undang Republik Indonesia Nomor 41 Tahun 1999 Tentang Kehutanan.

[9] Hetti Rahmawati, Local Wisdom Dan Perilaku Ekologis Masyarakat Dayak Benuaq, Jurnal Indigenous Vol. 13, No. 1, Mei 2015: 72-78 